\begin{tabular}{|c|c|c|c|c|c|c|}
\hline \multirow{4}{*}{ Impact Factor: } & ISRA (India) & $=4.971$ & SIS (USA) & $=0.912$ & ICV (Poland) & $=6.630$ \\
\hline & ISI (Dubai, UAE & $=0.829$ & РИНЦ (Russia) & $=0.126$ & PIF (India) & $=1.940$ \\
\hline & GIF (Australia) & $=0.564$ & ESJI (KZ) & $=8.716$ & IBI (India) & $=4.260$ \\
\hline & JIF & $=1.500$ & SJIF (Morocco) & $=5.667$ & OAJI (USA) & $=0.350$ \\
\hline
\end{tabular}

\section{SOI: $1.1 /$ TAS $\quad$ DOI: $10.15863 /$ TAS \\ International Scientific Journal Theoretical \& Applied Science}

p-ISSN: 2308-4944 (print)

e-ISSN: 2409-0085 (online)

Year: 2020

Issue: 03

Volume: 83

Published: 30.03 .2020

http://T-Science.org
QR - Issue

QR - Article
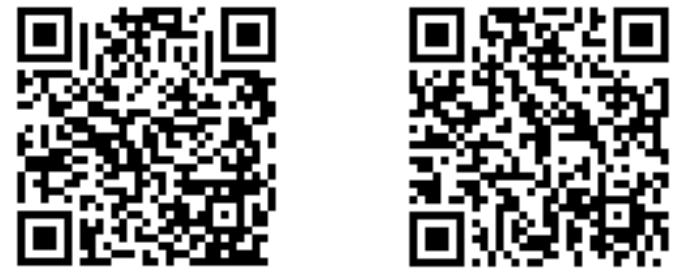

Dilfuza Obidovna Kamolova

The Bukhara engineering and technological institute Senior teacher of The "Uzbek language and literature" department

\title{
FEATURES OF CHILD MEMORY AND ITS DEVELOPMENT
}

Abstract: as the whole mental development of a human being consists mainly of memory, memory begins to develop from the earliest days of the child's life. The child's first signs of memory become apparent when he or she recognizes the people and objects in the vicinity. This is evident from the actions we take when a child sees something familiar to him. For example, when a child sees someone close to him, he or she may feel stranger or consider the stranger an alien. In young children, the ability to identify themselves allows them to remember what they perceive. As a child grows into adulthood, he develops complex memory patterns, or memory. Children will be able to remember things and events that they have learned since then.

Key words: features of child memory, type of memory, children's imagination, development of memory, senior groups, early childhood period.

Language: English

Citation: Kamolova, D. O. (2020). Features of child memory and its development. ISJ Theoretical \& Applied Science, 03 (83), 362-365.

Soi: http://s-o-i.org/1.1/TAS-03-83-67 Doi: crossef https://dx.doi.org/10.15863/TAS.2020.03.83.67

Scopus ASCC: 3304.

\section{Introduction}

The role of children's imagination is very important. Because of their imagination, children can easily remember past events, for example, if you tell a child what is wrong, he or she will look around for it. Growth of speech is very important in the development of memory. During this time, the child will be able to perceive things and events not only directly but also through the names of these things and events. They also enrich their memories by asking and listening to adults. In early childhood period, all memory processes begin to be seen. For example, a young child will be able to remember it mechanically, that is, without first understanding it. It has its own peculiarities, of course. First of all, as we have already mentioned, children have little experience in life, they do not yet know many things, but they are often remembered for their conflict in life. Secondly, the plasticity of the nervous system in children is greater than that of adults. For this reason, it is not difficult for children to remember mechanically.

\section{II.Literature review}

Children also develop very early in their sense of meaning. For example, early childhood children love some of the stories they love and some hate. In general, the content of stories affects children and gives them a sense of well-being that suggests that children understand the meaning of the story. Early childhoods occur as a result of involuntary recall. They are reluctant to remember things and events that are of interest to them. Remembering and anamnesing something is an association. They do not deliberately remember them. When something else needs to be remembered in the game, other associations come to mind as a result.

\section{III.Analysis}

Development of memory in preschool children. Kindergarten children (especially small group children) are reluctant to remember what is important to them and what they are passionate about. They do not set themselves the goal of remembering them and have not yet been able to set goals. It is no coincidence that in preschool age children are predominantly forced to remember. There are a number of reasons. Every educator must know the characteristics of a child's memory. This is where children's memory can be developed properly. The difference in the memory of preschool children from 


\begin{tabular}{|c|c|c|c|c|c|c|}
\hline \multirow{4}{*}{ Impact Factor: } & ISRA (India) & $=4.971$ & SIS (USA) & $=0.912$ & ICV (Poland) & $=6.630$ \\
\hline & ISI (Dubai, UAE & $=0.829$ & РИНЦ (Russia & $=0.126$ & PIF (India) & $=1.940$ \\
\hline & GIF (Australia) & $=0.564$ & ESJI (KZ) & $=8.716$ & IBI (India) & $=4.260$ \\
\hline & JIF & $=1.500$ & SJIF (Morocec & $=5.667$ & OAJI (USA) & $=0.350$ \\
\hline
\end{tabular}

adults is primarily due to the peculiarities of high nerve activity. According to the results of research conducted by a number of psychologists, kindergarten-age children have the following characteristics: firstly, the nervous system of kindergarten children is very plastic, just like the early childhood period nervous system, meaning that their nervous systems are highly elastic. For this reason, time-series associations can be formed very easily in children of this age. The characteristics of the nervous system in children do not affect their ability to remember. As a result, kindergarten children will remember songs, rhythmic poems, interesting and profound impressions and will remember them very quickly. Secondly, although the nervous system in kindergarten-age children is mild, the time-to-time associations that occur may be very unstable. Therefore, different things and events that are perceived by children of this age will not be stored in their memories for long. Not only do they remember quickly, but they quickly forget. Often things and events are preserved in preschoolers' memories, depending on how emotional these events and cases are affecting the child. Thirdly, kindergarten-age children are poor at braking compared to excitation in the nervous system. As a result, they are confused with many things at once. If a kindergarten boy is asked to describe what he perceived to be a festive holiday, he cannot tell it in a meaningful and systematic way. In this case, the child starts with what he has accidentally remembered. Because a lot of things you see at once are completely confusing. The child has no system in what he or she remembers, so the child will be able to speak first, from the first impression, or from the memory. This means that if a kindergarten child is exposed to too many things at the same time, they will blend everything together and not even remember. Experience has shown that middle-aged and older kindergarten children have little or no ability to memorize and remember mechanically. However, this does not mean that as children grow older, their memory is weakened. The point is that as children grow and experience more and more speech, they are more likely to remember things that they need, rather than what they are supposed to be. It should also be noted that in recent years, preschoolers have the impression that logical remembering is preferable to logical remembering. Mechanical remembering was opposed to logical remembering. Recent experimental studies have shown that preschoolers play an important role in understanding the meaning of words. But the logic of preschoolers is evident when they are given a full understanding of the material. In preschoolers, children have more memory. That is why they remember what they saw in relation to what they heard. The main reason is that, firstly, perceptions of kindergarten children have a specific image. Secondly, they have not yet formed a complete speech. Children will be able to remember what is being said only after they have mastered the speech in senior groups. Children often remember most things during game activities. For this reason, their memories are often episodic and random, making it difficult to put what they remember into a particular system. As a result, the memories of children are confused and intertwined. As a result, it will be difficult to remember. It is up to the educators to eradicate the memory disorders inherent in preschoolers and to increase memory. The educator should select the material that the children need to remember to suit their age. It is important to use different games to teach children memory. Generally, the facilitator should always supervise the child to remember and recall the material. Because all types of kindergartenage memory begin to grow. However, it is characteristic that among the main types of memory (such as figurative, mechanical, logical) memory moves more strongly. This is why children of this age can easily learn different activities and play music. Mechanically mastered speech material also partially moves into memory. For this reason, kindergarten children learn to recite poems in a variety of fastpaced rhythms. For example, the "count" before hiding a game of hiding. There is no point in counting the slacker game, but it has a very expressive and rhythmic sound. Although preschool children have good emotional memory, this type of memory is stronger in children than in adults. Adults will never forget some of the things and events that were emotionally disturbing. Kindergarten children can sometimes forget about their emotional effects. Educators and parents also play a very important role in children's memory. When speaking with a child, the talk should be simple, pronunciation and clear. Memory development does not end during the childhood of the kindergarten, but changes and grows according to the child's further development, that is, education and lifestyle.

\section{IV.Discussion}

Experiment. Experimentation is one of the main methods of scientific knowledge. The main difference from this observation is that the researcher is actively influencing the situation under study, manipulating one or more variables. In the experiment, mental properties are studied in special conditions. Two types of experiment are distinguished: laboratory experiment and natural experiment. Laboratory experiments are carried out in specially equipped places under strict control. In the case of a natural experiment, he does not know that it is the object of the experiment. This will eliminate the probability of such tests, such as emotional stress in the laboratory experiment, the desire to alter the results of the experiment. For example, you may want to take a preschool child to a separate room where he/she can read a series of words and then ask them to return. However, this is not unusual for a child. Therefore, the 


\begin{tabular}{|c|c|c|c|c|c|c|}
\hline \multirow{4}{*}{ Impact Factor: } & ISRA (India) & $=4.971$ & SIS (USA) & $=0.912$ & ICV (Poland) & $=6.630$ \\
\hline & ISI (Dubai, UAE & $=0.829$ & РИНЦ (Russia & $=0.126$ & PIF (India) & $=1.940$ \\
\hline & GIF (Australia) & $=0.564$ & ESJI (KZ) & $=8.716$ & IBI (India) & $=4.260$ \\
\hline & JIF & $=1.500$ & SJIF (Morocec & $=5.667$ & OAJI (USA) & $=0.350$ \\
\hline
\end{tabular}

emotional stress (anxiety, suspicion, etc.) of the child does not allow the child to begin the task as much as possible. This means that the results obtained from the experiment cannot be valid. If you have been tasked with playing with the child and shopping in the store for what he has been given as a customer, it's easy to determine what he or she has forgotten or forgotten. Therefore, the results of natural experiments in this way are more accurate. A number of requirements must be met when organizing and conducting experimental research. These requirements are systematized by G.U.Uruntayeva and Y.A.Afonkina:

1. At the planning stage, it is necessary to clearly define the purpose of the study, the composition of the tests, the methods used in the experiment, the conditions (place and time) of the experiment, and all necessary conditions.

2. Establish a trusting relationship with the child participating in the experiment during the experiment, give a friendly, warm tone to the dialogue, put the child in front of the child, and ignore the child's mistakes, it is necessary to adjust the pace of the child's individual-psychological characteristics. The experiment with the child should not be long and should not be altered during the experiment. Usually, the experimenter is the person who completes the record of the experiment in addition to the researcher. The other two types of experiment - deterministic experiment and formative experiment are also differentiated. In the exploratory experiment, certain characteristics of the child's mental development are noted. For example, it is possible to determine whether parents' disputes affect their child's emotional state. This requires identifying adult children in a disputed family and learning about their emotional state, and comparing the results with those of other children. The results of the comparison suggest that there is a link between parent-child conflict and child emotional development. Experimental experiments reveal an active effect of the experimenter on the changes that occur. For example, it is possible to determine how the improvement in parenting affects the child's emotional state. For this, it is necessary to compare the emotional characteristics of the child with improved parenting, or to compare the emotional characteristics of the children with whom the parent relationship is controversial, or the subsequent emotional characteristics of the child. In some cases, the control experiment also differs. This experiment is similar to the multivariate experiment. The purpose of the transfer is to determine what is the role of the impact on the changes in the active group. To do this, the results of the control group that are not affected are compared with the active group. If the difference is significant, then it is concluded that the changes in the first group are caused by the effect of the changes.

Request. Inquiry is a method used to collect primary verbal information during direct or indirect interaction between the researcher and the respondent.
The survey may be in the form of a questionnaire or an interview. The questionnaire will respond to written questions and oral questions during interviews. The request is divided into the following steps:

1. Epigraph. Here the examiner's ideas are directed in a specific direction and the testers are invited to answer the questions.

2. Instructions. The examiner is told how to respond to questions during the survey, and how the data is used.

3. Adaptation to Requests. It focuses on answering the quiz questions, building selfconfidence, building a relationship of trust that gives the impression that the questions can be answered as you wish. For this purpose, the survey first asks emotional, neutral, easy questions.

4. Achieving the goal. This will provide you with the basic information you need. For this, the questions at this stage are important for both the researcher and the pilot.

5. Overcoming stress. This eliminates the sentiment of the whole query process regarding the questions asked. This can be done by asking relatively simple, positive emotional questions, such as the social demographic characteristics of the examiner. The questions asked to the examiner are not separate. They are the rings of a single chain.

One question in the request is pertinent to the next. Therefore, special attention should be paid to the following questions:

1. One question and one answer should not affect the answers to the following questions.

2. The question after a particular question should not be completely shifted to another subject, nor should the subject change dramatically from one subject to another.

3. External expression of questions should involve the testers (should be symmetrically correct, questions should be beautiful and understandable by written or oral).

4. The individual characteristics of the test takers and the length of the inquiry should be consistent (for example, using 5-6 questionnaires for parent interviews). 5. It is advisable to express the words of gratitude and appreciation to the examiner at the end of the survey - "Thank you for your answers" and "Thank you for your help".

Projective methods. Project method is one of the methods of personal study. It creates experimental situations that can be interpreted by testers. By analyzing the test's interpretation, certain conclusions about its personality are made. This is because when interpreting a particular experimental situation, the projection mechanism exposes its own experiences, thoughts, dreams, fears and anxieties. Typical proactive techniques used in working with preschool children are: "Bola appertseptsiya testi", "Oilaviy ustanovkalarning Jekson testi", "Dyuss ertaklar 


\begin{tabular}{|c|c|c|c|c|c|c|}
\hline \multirow{4}{*}{ Impact Factor: } & ISRA (India) & $=4.971$ & SIS (USA) & $=0.912$ & ICV (Poland) & $=6.630$ \\
\hline & ISI (Dubai, UAE & $=0.829$ & РИНЦ (Russia & $=0.126$ & PIF (India) & $=1.940$ \\
\hline & GIF (Australia) & $=0.564$ & ESJI (KZ) & $=8.716$ & IBI (India) & $=4.260$ \\
\hline & JIF & $=1.500$ & SJIF (Morocce & $=5.667$ & OAJI (USA) & $=0.350$ \\
\hline
\end{tabular}

metodikasi" and so on. The application of these techniques is mainly done in the individual work process, which takes a long time. It takes a great deal of research to interpret the results of a project-based research.

\section{V.Conclusion}

Activity learning method. When it comes to learning preschool children through learning about activity, first of all, it involves analyzing the effects of children's visual activity. For this reason, methods based on the study of visual arts are called graphical methods. Graphic techniques include drawing techniques "Avtoportret", "Erkin mavzudagi surati”, "Dunyo surati", "Oila rasmi" , "Oilaning kinetik surati” , “Uy, daraxt, odam ”, "Geometrik shakllardan odam rasmini yig 'ish", "Daraxt”, "Grafik diktant" and more.
Test. Testing is a set of tasks that are used to measure the level of development of a particular psychological quality. The test method uses certain standard tasks and situations (tests). This method has a number of advantages: testers;

- it can be conducted with a large group of

- calculation and processing of results is much easier and simpler. The main disadvantage of the method is that it cannot inform the child's future development.

Psychology currently has a set of tests that identify the characteristics of preschool children, their emotional traits, their motivational field characteristics, their individual-typological characteristics, and the child's cognitive processes.

\section{References:}

1. Saidnazarova, J. (2006). "Health and care of children".

2. Kern, A. (2005). "School readiness tests".

3. Effeldt, A. (2004). "Reversive test" (check for child mortality).

4. (2007). The Güpingen "Examining school readiness.

5. Tuvalov, T. (2013). "Preparing Children to School", Samarkand.

6. Boltaev, M. (2010). "Uzbek reunion”, Samarkand State University named after Alisher Navoi.

7. Nishanova, Z., \& Alimova, G. (n.d.). Bolalar psixologiyasi va uni o'qitish metodikasi.

8. Kadirova, N. S., \& Akhmedova, Sh.N. (2019). Style and skill: critic's artistic ability.
International Journal of Innovative Technology and Exploring Engineering (IJITEE) ISSN: 2278-3075, Volume-8, Issue-9S3, July 2019.

9. Kurbanova, G.N. (2019). Development of professional thinking through communicative skills among students of medical universities. International Scientific Journal Theoretical Applied Science. Impact Factor. 24090085(online) Published: 30.11.2019. pp.550553.

10. Kurbanova, G.N. (2020). The role of ancestral heritage in the development of professional thinking of future professionals. International Scientific Journal Theoretical Applied Science. Impact Factor. 2409-0085(online) Published: 30.01.2020. pp.447-450. 